\title{
Intangible links between household livelihoods and food security in Solomon Islands: implications for rural development
}

\author{
$\underline{\text { Hampus Eriksson }}^{1,2}, \underline{\text { Reuben Sulu }}^{3}, \underline{\text { Jessica L. Blythe }}^{4}, \underline{\text { Jan van der Ploeg }}^{2}$ and Neil Andrew ${ }^{2}$
}

\begin{abstract}
Livelihood diversification has been the heartbeat of rural development projects over the past two decades. Many livelihood diversification programs are based on the often implicit assumption that introducing livelihood activities will translate into improved livelihood outcomes. In this study we analyze survey data from 235 households in Langalanga Lagoon, Solomon Islands. We explore relationships between household livelihoods and food security to guide the types of activities that may be appropriate for rural development planning. Results show high rates of food insecurity, where half of the surveyed households were moderately food insecure and a quarter of households severely food insecure. Importantly, we do not find any links between household livelihoods activities and food security; households valued livelihoods very differently. We discuss the implications of these findings for rural development planning.
\end{abstract}

Key Words: livelihood diversification; Pacific Islands; rural development; rural livelihoods; small-scale fisheries; Solomon Islands

\section{INTRODUCTION}

Diversifying livelihoods has become a key strategy to disrupt social-ecological traps by seeking to decouple poverty and overexploitation dynamics in many parts of the world (e.g., Barrett et al. 2001, Ellis and Allison 2004, Cinner 2011, Haider et al. 2018). Interdisciplinary research has focused on how poor or vulnerable households endure or succeed under difficult circumstances by examining the composition of their livelihoods (e.g., Collins et al. 2009, Blythe et al. 2014, Finkbeiner 2015, Mills et al. 2017, Hanh and Boonstra 2018). Ellis (1998, 2000) clearly articulates how diverse livelihood assets increase the capabilities of rural households to raise their living standards and manage uncertainty. As a whole, the literature is rich with examples where some measure of diversity, e.g., crop, income sector, or social network diversity, has a positive impact on the ability of individuals or households to cope with shocks, handle environmental change, or improve output (e.g., Silvestri et al. 2015, Haider et al. 2018). This learning is particularly important for small-scale fishers in the Global South, who often pursue a range of cross-sectoral activities to make ends meet (Allison and Horemans 2006, Cinner and Bodin 2010, Daw et al. 2012, Blythe et al. 2015).

A weakness of the livelihood diversification paradigm is that it implicitly infers that, in almost every context, people should be doing more, and be doing something different. There is also a conceptual muddiness in the livelihood diversification narrative: patterns of livelihood diversity have been translated into a normative process that aims to diversify livelihoods as practice for development initiatives. Diversification of rural livelihoods has become central to both development and environmental policy and practice (e.g., CARE 2008, Jennings and Manlutac 2015, SPC 2015). This is an area where there is still much to learn for both rural development and conservation programs because diversification can also expose new vulnerability (Lauer 2014, Eriksson et al. 2017). Kotschy et al. (2015) and Hanh and Boonstra (2018) have begun to explore the limits to livelihood diversity and diversification. At some point, the benefits from having multiple sources of livelihoods can become outweighed by the effort to sustain them and can depend on which activities are involved in the livelihood portfolio (Béné et al. 2011). Simply adding activities can sometimes generate additional burden for household members, especially for women, who are often household caretakers and assume responsibility for additional household activities (Chant and Sweetman 2012, Cohen et al. 2016). People's assets and their capability to engage in new activities are highly context dependent (Gautam and Andersen 2016).

Given the juxtaposition between the nearly universal support for livelihood diversification in development programs and the highly diverse and context specific nature of rural livelihoods, the purpose of this paper is to explore the relationship between livelihoods and food security in rural households in Solomon Islands. We analyze survey data from 235 households in Langalanga Lagoon to evaluate the influence of livelihood activities on households' food security and to examine the livelihood activities of those households that are more food secure. Understanding what sources of livelihood provides greater input to food security is important to guide the design of rural development programs.

\section{METHODS}

\section{Livelihood context and study site}

Langalanga Lagoon is a large lagoon system on the west coast of Malaita Province in Solomon Islands (Fig. 1) and is one of the most densely populated regions of the country (SINSO 2011). The lagoon is inhabited by the "saltwater people" whose livelihoods revolve around the sea (Sulu et al. 2015). Historically, the Langalanga people bartered fish and shells for root crops and vegetables with the "bush people," the Kwara'ae. These were shifting cultivators who inhabited the forested hinterlands of the lagoon (Ivens 1930, Burt 1994). The saltwater people built artificial islands of coral rocks on reefs and in the mangrove swamps, and specialized in the production of tafuli'ae, strings of

\footnotetext{
${ }^{1}$ WorldFish, Honiara, Solomon Islands, ${ }^{2}$ Australian National Centre for Ocean Resources and Security (ANCORS), University of Wollongong, Australia, ${ }^{3}$ Pacific Islands Forum Fisheries Agency (FFA), Honiara, Solomon Islands, ${ }^{4}$ Environmental Sustainability Research Centre, Brock University, Canada
} 
Fig. 1. (A) Map of Solomon Islands. Location of Langalanga Lagoon indicated by square in Malaita Province. (B) Hook-andline fishing over reef is a common fishing method. (C) Langalanga is adjacent to Auki, the main trading center of the province, where large volumes of fish are sold. (D) Woman shaping shell discs on a string for shell money (tafuliae) production, an important livelihood and cultural feature of the lagoon. (E) Many households reside on artificial islands in the lagoon. (F) Household gardening of crops is an important food- and income-generating livelihood for people with access to arable land.

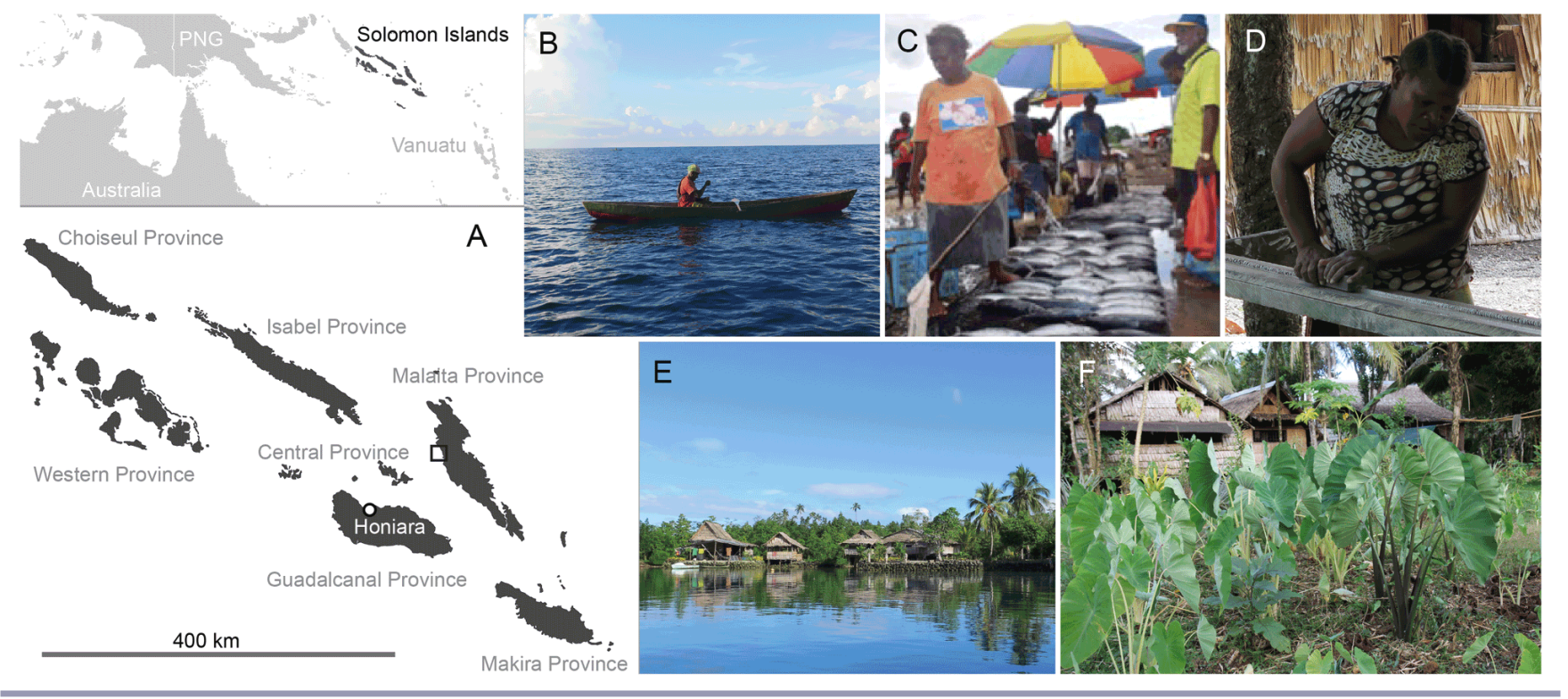

polished shells that are traditional wealth items used throughout the archipelago for trade, feasts, and compensation and marriage payments (Cooper 1971, Goto 1996, Guo 2006).

European contact fundamentally altered livelihoods, trade networks, and social relations in the lagoon. The labor trade and evangelization efforts provided new material goods such as steel axes, fishhooks, and guns, which enhanced agricultural productivity, but also increased gender inequality and led to widespread violence (Moore 2017). In 1909, the British colonial government established a station at the northern tip of the lagoon, present-day Auki town. The Langalanga dominated interisland trade in the protectorate, and in the 1930s several shipyards were established in the lagoon (Guo 2011). Copra and cocoa became important agricultural commodities.

Despite these developments, fishing remains the primary livelihood activity for the Langalanga people (PGSP 2016); however, overfishing has severely impacted on marine resources in the lagoon (Eriksson et al. 2016). Horticulture is the other main source of food and income for most households. Typical daily diets in the area comprise fish, sweet potato, rice, and slippery cabbage (Albert et al. 2020). Most agricultural land is owned by Kwara'ae clans under customary law, which restricts investment in agricultural development by Langalanga people. The civil conflict that paralyzed the country in the early 2000 s reinforced these ethnic differences and inequalities. The limited prospects beyond the subsistence economy, a situation that has been characterized as "poverty of opportunity" (Narsey 2011), has led to rapid urbanization; young and educated people in particular migrate to Honiara in search of a better life. Health care, education, infrastructure, and other government services in the rural areas remain very poor, despite ambitious government plans and substantial international development aid after the civil conflict (World Bank 2017).

\section{Household survey and analysis}

There are approximately 2100 households in the Langalanga Lagoon area, including inland villages and adjacent communities on the fringes of Auki (SINSO 2011). In March 2013, we conducted a socioeconomic survey of 235 households in 12 villages using a structured questionnaire (the questionnaire is provided in Appendix 1). The survey was carried out by a team of four male and two female Solomon Islanders. Two of the team members were from Langalanga and could speak the local language; all members were familiar with the culture and fluent in Solomon Islands Pijin, the lingua franca of the country. The survey sought to sample around $30 \%$ of households per village. The Solomon Islands 2009 census (SINSO 2011) was consulted to determine the actual number of households to be sampled in each village (see Appendix 2 for detailed sampling effort). For small villages (particularly those on artificial islands), with usually 10 or fewer houses, all households were interviewed. Heads of households were sought for the survey. If other family members were present during the interview, they could assist in contributing to answers. The composition of household members was recorded.

Survey questions were based on the Household Food Insecurity Access Scale (HFIAS). Responses were used to calculate HFIAS scores and associated food security categories $(1=$ food secure, 2 = fairly food insecure, $3=$ moderately food insecure, $4=$ severely food insecure) following the methods of Coates et al. (2007). The survey questions elicited whether households were worried about availability of food; had food available; had enough food to eat; and were eating the foods that they preferred in the four weeks prior to the survey. 
To elicit trends in HFIAS scores according to household demography, we carried out multiple regression analysis as described by Logan (2010). The total number of household members was defined as the people who regularly sleep and eat at the dwelling. The household child-to-adult ratio was calculated. The survey also asked recall questions about income and we calculated household per capita income for analysis against HFIAS trends.

Survey respondents were also asked questions about which household livelihood activities generate food and income. The question asking respondents to list all livelihoods was openended. This worked well for casual labor type occupations, e.g., carpentry or boat maintenance, but crop cultivation was described as "gardening," e.g., crops were not specified. Similarly, "fishing" was not further detailed into specific methods used, e.g., hook and line or lamp fishing for squid. Respondents indicated which household members were responsible for each livelihood activity to build a picture of all household livelihoods. Respondents were asked to score the importance of each livelihood activity to their household (on a 1-4 scale). In this study, we interpret a livelihood value to be the level of perceived importance to overall household food and income as scored in the survey. In our analyses, we assigned a zero (0) score to all livelihood activities that were not scored by the household (not part of their portfolio), to enable us to quantify how unimportant or unsuitable some livelihood activities were. We did not measure fish catches, garden yields, or incomes directly.

We calculated linear regressions to predict HFIAS based on number of reported household livelihoods and average weekly household income per capita. For multivariate testing of any livelihood activity composition effect on HFIAS, we calculated the Bray-Curtis dissimilarity matrix and ordinated the data in nonmetric multidimensional space. We tested the hypothesis that household livelihood activity composition influenced HFIAS using analysis of similarities (ANOSIM) with 999 permutations in the VEGAN package in $\mathrm{R}$ as described by Oksanen et al. (2013).

To supplement the quantitative analyses from Langalanga, we provide qualitative information summarizing participatory action research in the location (Schwarz et al. 2013, Sulu et al. 2015, van der Ploeg et al. 2015, Sukulu et al. 2016, Teioli et al. 2018), including collaboration with OKRONUS, a communitybased organization that is spearheading local sustainability and development initiatives. OKRONUS is an acronym for the six villages that are working together in this local initiative (Oibola, Kona, Radefasu, Oneoneabo, Ura, and Sita). Our organization (WorldFish) has worked with people from these villages since 2011 to formalize a community-based organization, implement training events, and launch a locally managed marine area (LMMA).

\section{RESULTS}

\section{Household food security}

Only 14\% of the households surveyed were food secure (Fig. 2). Half of the surveyed households reported moderate food insecurity and a quarter of the households identified themselves as severely food insecure. People who rely on natural resources throughout the year reported experiencing fluctuations in access to these resources for food and income. Our study was conducted in March at the end of the northwestern trade winds, koburu, which is generally the lean period in the lagoon. It is likely that the results of our food security measurements would have been different if sampled at a different time of the year. Nevertheless, it gives an idea about the broad pattern of food insecurity in Langalanga.

Fig. 2. Frequency distribution of households in the four categories of Household Food Insecurity Access Scale (HFIAS) in Langalanga Lagoon, Solomon Islands.

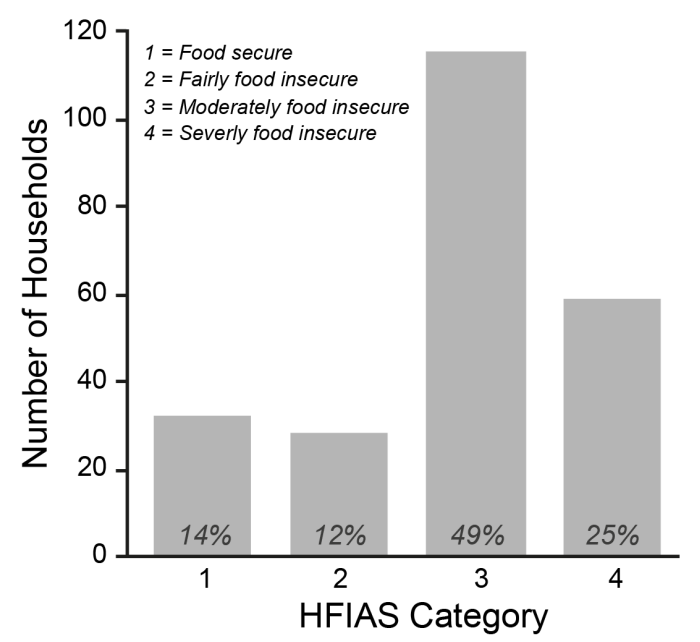

Food security and household composition

We sought explanation to the food security pattern first in the size of the household and the household ratio of children to adults. Other studies have found that family size influences food security. For example, the literature indicates that larger families tend to be less food secure (Olayemi 2012), but that this is not a linear relationship and both external factors and family demography plays in (Garret and Ruel 1999). To predict the HFIAS score from household size and the ratio of children to adults, and the interaction of these variables, we calculated multiple regression analysis. In our case, the data provided no evidence that the tested household variables, or the interaction variable, predicted HFIAS scores (Table 1).

\section{Food security and household income}

Our analyses indicated that food security in Langalanga households is not a direct product of the internal household attributes that we sampled. We sought to explore the relationship between reported income and the household HFIAS. Higher income is broadly considered a key factor in reducing hunger (Maxwell and Smith 1992, Beyene and Muche 2010), but in agricultural settings household food production strategies can offset such income trends (Silvestri et al. 2015). We calculated a linear regression to predict HFIAS based on reported average weekly household income per capita. Household per capita income varied widely and no significant regression was found $\left(F_{1,233}<0.00, p=0.99\right)$, with an $R^{2}$ of 0.00 . It is possible that the method of self-reporting income, although commonly used in structured questionnaire surveys (e.g., Silvestri et al. 2015), did not provide an accurate measure of the household's overall financial situation, which may fluctuate over the year. 
Table 1. Output from multiple linear regression.

\begin{tabular}{lcccc}
\hline \hline Coefficient & Estimate & SE & $t$-value & $p$ \\
\hline Household size & -0.15 & 0.19 & -0.78 & 0.44 \\
$\begin{array}{l}\text { Household children to adult } \\
\text { ratio }\end{array}$ & -1.37 & 1.40 & -0.98 & 0.33 \\
$\begin{array}{l}\text { Household size * Household } \\
\text { children to adult ratio }\end{array}$ & 0.33 & 0.20 & 1.65 & 0.10 \\
\hline
\end{tabular}

Pacific Island food systems are transforming toward a higher proportion of imported processed foods (Snowdon et al. 2013, Bell et al. 2016). This is also the case in Solomon Islands (Andersen et al. 2013, Albert et al. 2020) and store-bought foods contribute to the diets of households in Langalanga (Sulu et al. 2015). As part of this transition, an increasing reliance on incomegenerating livelihoods for food sourcing might be expected. All HFIAS categories (from food secure to severely food insecure) had a relatively equal distribution of households relying solely on income-generating livelihoods (Table 2). Previous research suggests that households with higher incomes would rely more on purchased foods rather than self-produced food (Campbell 2015), but we were not able to tease out whether such relationships contributed to household food security in our dataset.

Table 2. Distribution of households that do not engage in foodproducing livelihood activities (fishing and gardening) for each Household Food Insecurity Access Scale (HFIAS) category.

\begin{tabular}{lcc}
\hline \hline HFIAS category & $N$ & $\begin{array}{c}\text { Households that do not fish and } \\
\text { garden }(\% \text { of } N)\end{array}$ \\
\hline 1. Food secure & 32 & $7(22)$ \\
2. Fairly food insecure & 28 & $7(25)$ \\
3. Moderately food insecure & $1-$ & $25(22)$ \\
& 16 & $12(20)$ \\
4. Severely food insecure & 59 &
\end{tabular}

\section{Household food security and livelihood patterns}

We sought further explanation for the differences in household food security by examining the data on the nature of household livelihoods. In total, 30 livelihood activities were recorded in the survey (Fig. 3). A linear regression was calculated to predict HFIAS based on number of livelihoods. No significant regression was found $\left(\mathrm{F}_{1,233}, p=0.95\right)$, with an $R^{2}$ of 0.00 . The number of livelihoods in a household does not predict its food security.

Clearly, different households in Langalanga are food secure to varying degrees. It is intuitive then to theorize that it is not the number but the specific type of livelihood activities that make some households more food secure than others. To explore this proposition, we examined the livelihood portfolios of households in each HFIAS category. The ordination analysis illustrated that livelihood portfolios between households in the four HFIAS categories were similar and overlapping (Fig. 4). We found no significant dissimilarity in livelihood composition between households belonging to the different HFIAS categories (ANOSIM: $R=0.01, p=0.30$ ).
Fig. 3. The livelihood activities recorded in the survey and their frequency among the 235 surveyed households.

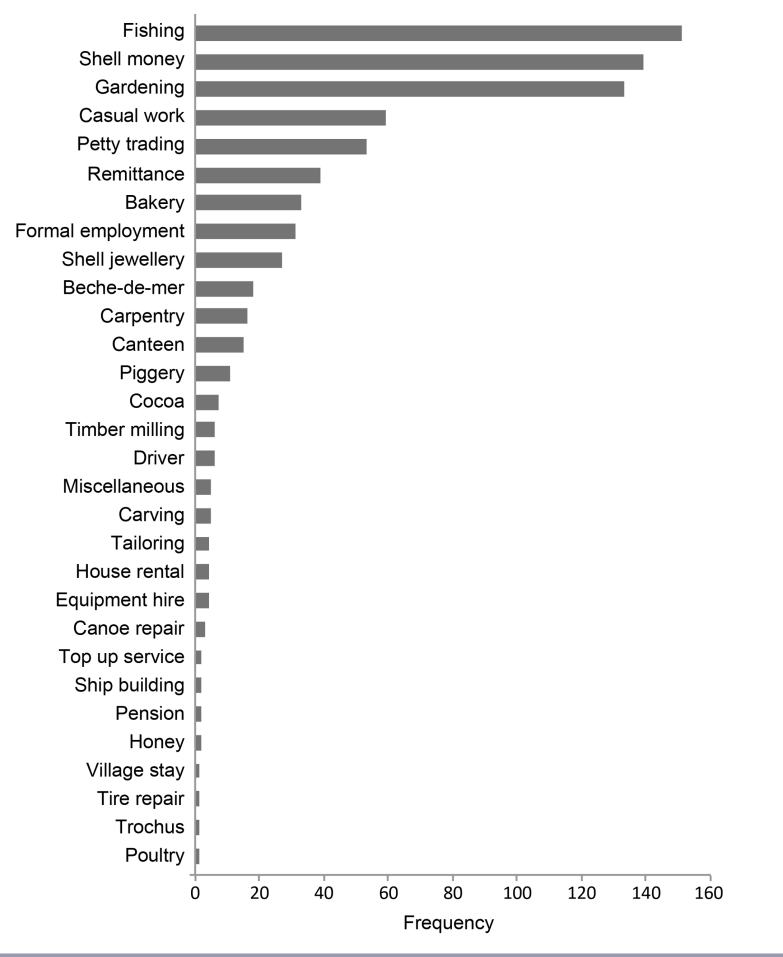

Fig. 4. Ordination plot of livelihood activity composition among the four Household Food Insecurity Access Scale (HFIAS) categories. Data have been ordinated from the BrayCurtis dissimilarity matrix.

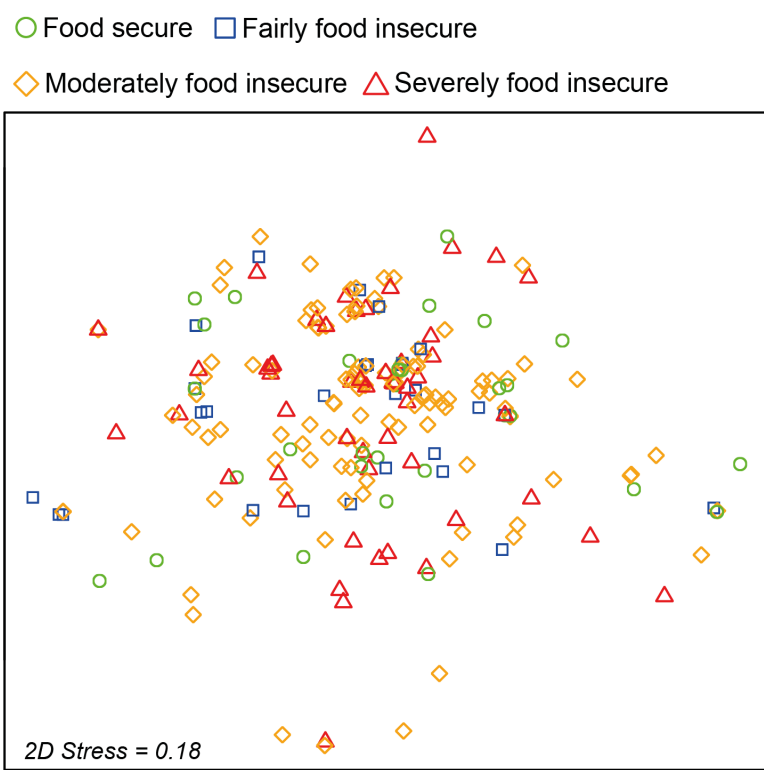


Learning from the livelihood strategies of relatively food secure households can help identify factors that can contribute to enhancing food security, and prioritize specific development interventions (Silvestri et al. 2015). In this vein, we expected to find that those households that categorize as food secure in Langalanga Lagoon would exhibit a dissimilar livelihood composition to food insecure households, something that would set them apart and offer us insights into livelihood strategies that build food security in the Langalanga context, but this was not the case. This shows that livelihood diversification as a desired development process is difficult to make operational in Langalanga: we cannot deduce an ideal set of livelihood activities that will achieve food security.

\section{Valuing livelihood activities}

Opportunities for people to diversify livelihoods vary in Langalanga Lagoon. For example, households within the lagoon are located at different distances from the urban center, Auki, and have differential access to arable land (Sulu et al. 2015). It is reasonable to expect that households have different opportunities to generate value from similar activities, and may invest differently in them. Therefore, we theorized that the value that a livelihood's contribution to a given household would differ from that of another household. To examine this proposition, we analyzed the distribution of how households value livelihood activities (Fig. 5). Across the 12 most common livelihoods, there is a clear pattern of varying values to households. Fishing is a key livelihood of Langalanga people for both food and income (Sulu et al. 2015, Roeger et al. 2016), but it is apparent from our analysis that households derive different value from fishing: 84 households scored it at highest importance, 85 households did not score it at all, and 66 households scored it at intermediate importance levels. Our data indicate that people make a living based on the opportunities that they see in front of them and the capacity that they have to pursue these opportunities. Even in an area that is known for its "saltwater people" with high reliance on the ocean, $36 \%$ of households derive no value from fishing.

These patterns highlight a shortcoming in the quantitative survey methodology (also see Chambers 1997). A greater emphasis on qualitative research would allow households to explain their sources of food security and insecurity in greater depth. For example, stressors, such as droughts and illness or deaths, can force households to rapidly reorganize and reprioritize livelihoods activities (e.g., Genoni 2012, Béné et al. 2014). It would be useful to explore what diversification processes might look like from the householder perspective. In addition, resource sharing between relatives is a strong feature of the culture of our case-study setting, so it is possible that our food security response variable might be influenced based on social institutions such as kinship, which we did not incorporate into our analyses. .0

\section{DISCUSSION}

The livelihood diversification paradigm has become central to development policy and practice (e.g., CARE 2008, Jennings and Manlutac 2015). In the small-scale fisheries sector in the Pacific, for example, livelihood diversification is actively promoted by donors, governments, and civil society organizations as a way to alleviate poverty, improve food insecurity, and reduce pressure of marine resources (O'Garra 2007, Gillett et al. 2008, SPC 2015). Coastal fisheries development programs have focused on promoting alternative livelihoods such as mariculture (Hambrey et al. 2011), ecotourism (Diedrich and Aswani 2016), sports fishing (Wood et al. 2013), fish aggregating devices (Albert et al. 2014), deep sea snapper fishing (Foale et al. 2017), and small-scale aquaculture (Blythe et al. 2017). Livelihood diversification also permeates development policy and practice in Solomon Islands (see Table 3 for recent development projects in Malaita Province). However, our findings challenge the assumption that a high diversity of activities leads to improved food security and complicates the process of what to actually do. There is a need to add nuance to the basic narrative that development programs should seek to diversify people's livelihoods.

Fig. 5. Frequency distribution of livelihood scoring by 235 households for the 12 most common activities in Langalanga Lagoon in $2013(0=$ not important, $1=$ somewhat important, $2=$ quite important, $3=$ important, $4=$ very important). Households scored the importance of livelihoods that they mentioned on a scale 1-4; livelihoods that were not mentioned were assigned a zero (0).

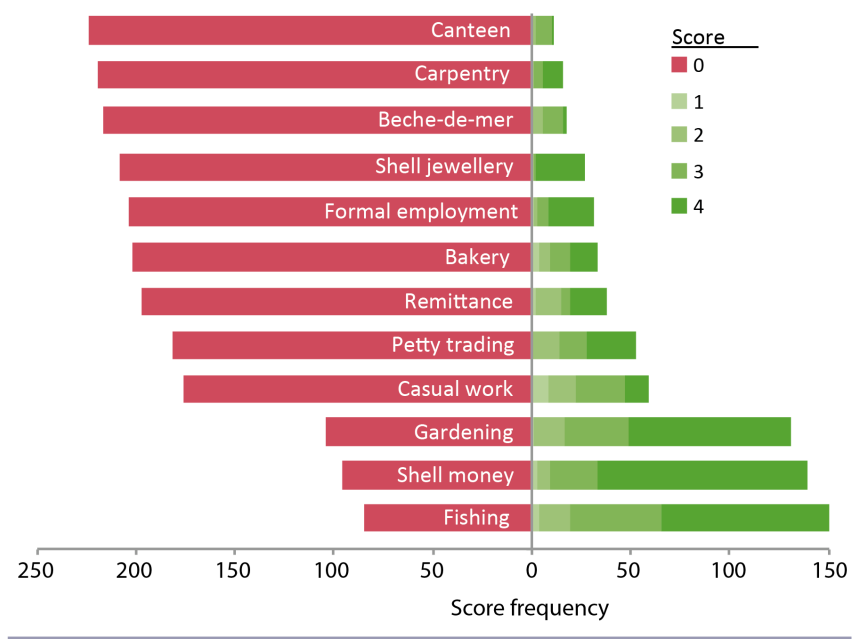

Efforts to diversify livelihoods that are not attuned to community capacity, needs, aspirations, and opportunities are unlikely to survive project lifetimes (O'Garra 2007, Govan 2011). Ineffective alternative livelihood initiatives to reduce fishing pressure and improve incomes for coastal fishers in the Pacific are poignant examples of how unreliable this narrative can be (Gillett et al. 2008, Hambrey et al. 2011). So, a challenge for development scholars and practitioners is to quantify and interpret the complex patterns of how people live their lives and incorporate this knowledge into the design of credible theories of change for development initiatives.

Since the 1990s, the sustainable livelihoods approach (SLA) has become the dominant structure for analyzing rural livelihoods (e. g., Chambers and Conway 1992, Allison and Horemans 2006, Morse and McNamara 2013). The principles within the SLA have stood the test of time and are clearly relevant for scientific inquiry, but it is not so easy to translate those principles into practice. In the words of Scoones (2009:185),

[A]lthough livelihoods analysis frameworks and methods definitely offer a way of uncovering complexity 
Table 3. Examples of rural development projects, which explicitly aim to diversify livelihoods and improve food security in Malaita Province, Solomon Islands.

\begin{tabular}{|c|c|c|c|c|}
\hline Implementing agency & Project title & Aim & Livelihood activity & Source \\
\hline World Vision & $\begin{array}{l}\text { Malaita Community } \\
\text { Resilience and Livelihoods } \\
\text { Project }\end{array}$ & $\begin{array}{l}\text { Enhance community } \\
\text { resilience for food and } \\
\text { livelihood security }\end{array}$ & Bee keeping & $\begin{array}{l}\text { https://www.wvi.org/sites/default/ } \\
\text { files/HEA } \% 20 \text { Fact } \% 20 \text { Sheet } \% \\
\text { 20Solomon } \% 20 \text { Islands } \% 20-\% \\
\underline{\text { 20Final } \% 20-\% 20 \text { updated } \%} \\
\text { 20April } \% 202013 . \text { pdf }\end{array}$ \\
\hline Save the Children & $\begin{array}{l}\text { Youth Outreach } \\
\text { Partnership Project }\end{array}$ & $\begin{array}{l}\text { Help youths engage in } \\
\text { income generating activities } \\
\text { and adopt a healthy lifestyle }\end{array}$ & $\begin{array}{l}\text { Piggery and poultry farms and } \\
\text { other income generating } \\
\text { activities }\end{array}$ & UNDP 2018 \\
\hline $\begin{array}{l}\text { Adventist Development } \\
\text { and Relief Agency } \\
\text { (ADRA) }\end{array}$ & $\begin{array}{l}\text { Youth Engagement and } \\
\text { Livelihood Project }\end{array}$ & $\begin{array}{l}\text { Improve livelihood } \\
\text { opportunities of youth } \\
\text { through microfinance }\end{array}$ & $\begin{array}{l}\text { Savings clubs, sewing, weaving, } \\
\text { furniture making }\end{array}$ & $\begin{array}{l}\underline{\text { https://www.dfat.gov.au/sites/ }} \\
\text { default/files/solomon-islands- } \\
\text { ngo-partnership-agreement-final- } \\
\text { report.pdf }\end{array}$ \\
\hline $\begin{array}{l}\text { United Nations } \\
\text { Development } \\
\text { Programme (UNDP) }\end{array}$ & $\begin{array}{l}\text { Strongem Waka lo } \\
\text { Community fo Kaikai } \\
\text { Projectt }\end{array}$ & $\begin{array}{l}\text { Enhance food security and } \\
\text { livelihood resilience in pilot } \\
\text { communities }\end{array}$ & $\begin{array}{l}\text { Supsup gardens and tilapia } \\
\text { farming }\end{array}$ & $\begin{array}{l}\text { https://www.adaptation-undp. } \\
\text { org/projects/af-solomon-islands }\end{array}$ \\
\hline $\begin{array}{l}\text { Foundation of the } \\
\text { Peoples of the South } \\
\text { Pacific International } \\
\text { (FSPI) }\end{array}$ & $\begin{array}{l}\text { Improving resilience and } \\
\text { adaptive capacity of } \\
\text { fisheries dependent } \\
\text { communities in Solomon } \\
\text { Islands }\end{array}$ & $\begin{array}{l}\text { Strengthen the livelihood } \\
\text { resilience of fishery- } \\
\text { dependent communities }\end{array}$ & Coral farming & $\begin{array}{l}\text { https://www. } \\
\text { povertyandconservation.info/en/ } \\
\text { org/o0364 }\end{array}$ \\
\hline $\begin{array}{l}\text { International Union for } \\
\text { Conservation of Nature } \\
\text { (IUCN) }\end{array}$ & $\begin{array}{l}\text { Mangrove Ecosystems for } \\
\text { Climate Change } \\
\text { Adaptation \& Livelihoods } \\
\text { Project }\end{array}$ & $\begin{array}{l}\text { Increase resilience to climate } \\
\text { change and improve } \\
\text { livelihoods }\end{array}$ & $\begin{array}{l}\text { Community-based resource } \\
\text { management }\end{array}$ & $\begin{array}{l}\text { https://www.iucn.org/downloads/ } \\
\text { mescal midterm.pdf }\end{array}$ \\
\hline WorldFish & $\begin{array}{l}\text { Strengthening community- } \\
\text { based natural resource } \\
\text { management to safeguard } \\
\text { food security }\end{array}$ & $\begin{array}{l}\text { Demonstrate the impact of } \\
\text { community-based resource } \\
\text { management on food } \\
\text { security }\end{array}$ & Fish aggregating devices & $\begin{array}{l}\underline{\text { https://digitalarchive. }} \\
\text { worldfishcenter.org/ } \\
\underline{\text { handle/20.500.12348/3758 }}\end{array}$ \\
\hline WorldFish & $\begin{array}{l}\text { Enhancing rural livelihoods } \\
\text { while governing marine } \\
\text { resources }\end{array}$ & $\begin{array}{l}\text { Design and implement } \\
\text { participatory livelihoods } \\
\text { enhancement }\end{array}$ & Solar-powered freezers & $\begin{array}{l}\text { https://rethink.earth/freezing- } \\
\text { fish-in-rural-solomon-islands/ }\end{array}$ \\
\hline
\end{tabular}

and diversity in ways that has often not been revealed before, the important question is: what happens next? Which option is best, and for whom?

In keeping with the SLA, various implementation manuals offer instructions for external agencies on how to facilitate a participatory process of diagnosing livelihood diversification options; see, as examples in the coastal and marine sector, the Sustainable Livelihoods Enhancement and Diversification manual (IMM 2008) and the New Idea for Coastal Fisheries diagnosis toolkit (Govan et al. 2019). Although these guides provide useful guidance for diagnosis of already identified livelihood ideas in a context, they offer little guidance for identifying equitable and effective ideas: how do households and development organizations choose from an endless list of possible livelihood activities?

In his overview of how the SLA has been adopted by various implementing agencies, Krantz (2001:4) writes the following:

[T] he best hope is to ensure that already identifiedl decided sector development initiatives fit with people's livelihood strategies and make them better at responding to the constraints and opportunities affecting the poor.

Although this approach seems rather opportunistic, it highlights how livelihood diversification often has been operationalized in practice. This statement also contradicts the participatory approach so often sought and promoted in this field (e.g., Chambers 1997). Embedded within this challenge is the complication of formulating programs that manage the potential trade-offs between seeking improvement to current food security (by enhancing a current single promising livelihood) and increased resilience against potential threats (by adding diverse livelihoods to the household portfolio). There remains much ambiguity in the literature about whether the objective of livelihood diversification is to reduce people's poverty now or to increase their resilience against threats later, or whether livelihood diversification can achieve both (see, for example, Fuller 2017).

Our own experiences in Langalanga Lagoon provide a good illustration of these difficulties. Over the past years our organization has worked with the community-based organization OKRONUS to establish an LMMA in the lagoon (Sukulu et al. 2016). As part of this process, we sought to identify alternative livelihoods activities to support households affected by the LMMA. Several activities, such as cultivating vegetables and fruits in so-called supsup gardens and modernizing the production of shell money were deemed uninteresting, unfeasible, or inappropriate by the leadership of OKRONUS. Efforts were made to introduce improved cooking stoves to reduce the cutting of mangroves, with limited results (Teioli et al. 2018). Community members in turn asked if our organization could play a mediatory role in arranging labor-based opportunities in Australia and New Zealand. This shows that, at least to some, local opportunities 
might not be preferred, and aspirations do not always align with the priorities and capabilities of external agencies (van der Ploeg et al. 2015). Identifying an activity that could encompass the very diverse needs and aspirations of people directly affected by the proposed LMMA in Langalanga Lagoon thus proved challenging, especially because cooperation and group activities - the modality commonly pursued by development agencies for diversifying livelihoods - did not align with the ideas and priorities of local people. Moreover, in a context of political patronage and aid dependence the identification of potential development opportunities can easily result in unrealistic expectations and frustrations (Foale 2001, Orirana et al. 2016).

\section{CONCLUSIONS}

A problem in rural development practice is that evidence on the benefits of livelihood diversity as an observed pattern has been translated into livelihood diversification as a desired process to be facilitated by externally funded programs. In Langalanga Lagoon, we do not find any tangible relationships between the livelihood activities of a household and its food security. These findings highlight the need to nuance development narratives about livelihood diversification and the processes through which development outcomes can be achieved. Continued research on the complex relationships between rural livelihoods and food security is warranted to support viable rural development programs that align with the context that they are operating within.

Responses to this article can be read online at: http://www.ecologyandsociety.org/issues/responses. $\mathrm{php} / 11709$

\section{Acknowledgments:}

This work was undertaken as part of the CGIAR Research Program on Fish Agri-food Systems (FISH). The household survey was conducted under the European Union project "Implementing an ecosystem approach to fisheries (EAF) in small-scale tropical marine fisheries" (Action DCI-ENVI2011/221352). The study was supported by SwedBio, a policy and practice program at the Stockholm Resilience Centre; and Australian Aid through the Australian Centre for International Agricultural Research (ACIAR) Project FIS/2016/300.

\section{Data Availability:}

The datalcode that support the findings of this study are available on request from the corresponding author, HE. The datalcode are not publicly available because of their containing information that is sensitive (e.g., family composition, food security, and incomes) for research participants.

\section{LITERATURE CITED}

Albert, J. A., D. Beare, A.-M. Schwarz, S. Albert, R. Warren, J. Teri, F. Siota, and N. L. Andrew. 2014. The contribution of nearshore fish aggregating devices (FADs) to food security and livelihoods in Solomon Islands. PLOS ONE 9(12):e115386. https://doi.org/10.1371/journal.pone.0115386
Albert, J., J. Bogard, F. Siota, J. McCarter, S. Diatalau, J. Maelaua, T. Brewer, and N. Andrew. 2020. Malnutrition in rural Solomon Islands: an analysis of the problem and its drivers. Maternal and Child Nutrition 16(2):e12921. https://doi.org/10.1111/mcn.12921

Allison, E., and B. Horemans. 2006. Putting the principles of the sustainable livelihoods approach into fisheries development policy and practice. Marine Policy 30:757-766. https://doi. org/10.1016/j.marpol.2006.02.001

Andersen, A. B., S. H. Thilsted, and A. M. Schwarz. 2013. Food and nutrition security in Solomon Islands. Working Paper: AAS-2013-06. CGIAR Research Program on Aquatic Agricultural Systems, Penang, Malaysia. [online] URL: $\underline{\text { http:// }}$ pubs.iclarm.net/resource centre/WF 3544.pdf

Barrett, C. B., T. Reardon, and P. Webb. 2001. Nonfarm income diversification and household livelihood strategies in rural Africa: concepts, dynamics, and policy implications. Food Policy 26 (4):315-331. https://doi.org/10.1016/S0306-9192(01)00014-8

Bell, J., M. Taylor, M. Amos, and N. Andrew. 2016. Climate change and Pacific Island food systems. CCAFS and CTA, Copenhagen, Denmark and Wageningen, the Netherlands.

Béné, C., L. Evans, D. Mills, S. Ovie, A. Raji, A. Tafida, A. Kodio, F. Sinaba, P. Morand, J. Lemoalle, and N. Andrew. 2011. Testing resilience thinking in a poverty context: experience from the Niger River basin. Global Environmental Change 21(4):1173-1184. https://doi.org/10.1016/j.gloenvcha.2011.07.002

Béné, C., A. Newsham, M. Davies, M. Ulrichs, and R. GodfreyWood. 2014. Resilience, poverty and development. Journal of International Development 26:598-623. https://doi.org/10.1002/ jid. 2992

Beyene, F., and M. Muche. 2010. Determinants of food security among rural households of Central Ethiopia: an empirical analysis. Quarterly Journal of International Agriculture 49 (4):299-318. https://doi.org/10.22004/ag.econ.155555

Blythe, J., M. Flaherty, and G. Murray. 2015. Vulnerability of coastal livelihoods to shrimp farming: insights from Mozambique. Ambio 44(4):275-284. https://doi.org/10.1007/ s13280-014-0574-z

Blythe, J. L., G. Murray, and M. Flaherty. 2014. Strengthening threatened communities through adaptation: insights from coastal Mozambique. Ecology and Society 19(2):6. https://doi. org/10.5751/ES-06408-190206

Blythe, J., R. Sulu, D. Harohau, R. Weeks, A.-M. Schwarz, D. Mills, and M. Phillips. 2017. Social dynamics shaping the diffusion of sustainable aquaculture innovations in the Solomon Islands. Sustainability 9(1):126. https://doi.org/10.3390/su9010126

Burt, B. 1994. Land in Kwara'ae and development in Solomon Islands. Oceania 64(4):317-335. https://doi.org/10.1002/j.1834-4461.1994. $\underline{\mathrm{tb} 02475 . \mathrm{x}}$

Campbell, J. R. 2015. Development, global change and traditional food security in Pacific Island countries. Regional Environmental Change 15:1313-1324. https://doi.org/10.1007/ s10113-014-0697-6

CARE. 2008. Introduction of livelihoods diversification activities to boost household incomes of vulnerable communities in 
Northern Kenya. CARE International in Kenya, Nairobi, Kenya.

Chambers, R. 1997. Whose reality counts? Putting the first last. Intermediate Technology, London, UK.

Chambers, R., and G. Conway. 1992. Sustainable sural livelihoods: practical concepts for the 21 st Century. IDS Discussion Paper 296. Institute of Development Studies, Brighton, UK.

Chant, S., and C. Sweetman. 2012. Fixing women or fixing the world? 'Smart economic', efficiency approaches, and gender equality in development. Gender and Development 20:517-529. https://doi.org/10.1080/13552074.2012.731812

Cinner, J. E. 2011. Social-ecological traps in reef fisheries. Global Environmental Change 21(3):835-839 https://doi.org/10.1016/j. gloenvcha.2011.04.012

Cinner, J. E., and Ö. Bodin. 2010. Livelihood diversification in tropical coastal communities: a network-based approach to analyzing 'livelihood landscapes.' PLoS ONE 5(8):e11999. https://doi.org/10.1371/journal.pone.0011999

Coates, J., A. Swindale, and P. Bilinsky. 2007. Household food insecurity access scale (HFIAS) for measurement of household food access: indicator guide. Version 3. Food and Nutrition Technical Assistance Project, Academy for Educational Development, Washington, D.C., USA.

Cohen, P. J., S. Lawless, M. Dyer, M. Morgan, E. Saeni, H. Teioli, and P. Kantor. 2016. Understanding adaptive capacity and capacity to innovate in social-ecological systems: applying a gender lens. Ambio 45:309-321. https://doi.org/10.1007/ s13280-016-0831-4

Collins, D., J. Morduch, S. Rutherford, and O. Ruthven. 2009. Portfolios of the poor: how the world's poor live on $\$ 2$ a day. Princeton University Press, Princeton, New Jersey, USA.

Cooper, M. 1971. Economic context of shell money production in Malaita. Oceania 41(4):266-276. https://doi.org/10.1002/ j.1834-4461.1971.tb01167.x

Daw, T. M., J. E. Cinner, T. R. McClanahan, K. Brown, S. M. Stead, N. A. J. Graham, and J. Maina. 2012. To fish or not to fish: factors at multiple scales affecting artisanal fishers' readiness to exit a declining fishery. PLoS ONE 7(2):e31460. https://doi. org/10.1371/journal.pone.0031460

Diedrich, A., and S. Aswani. 2016. Exploring the potential impacts of tourism development on social and ecological change in the Solomon Islands. Ambio 45(7):808-818. https://doi. org/10.1007/s13280-016-0781-X

Ellis, F. 1998. Household strategies and rural livelihood diversification. Journal of Development Studies 35:1-38 https:// doi.org/10.1080/00220389808422553

Ellis, F. 2000. Determinants of rural livelihood diversification in developing countries. Journal of Agricultural Economics 51:289-302. https://doi.org/10.1111/j.1477-9552.2000.tb01229.x

Ellis, F., and E. Allison. 2004. Livelihood diversification and natural resource access. Food and Agriculture Organization of the United Nations (FAO) Livelihood Support Programme Working Paper 9. FAO, Rome, Italy.
Eriksson, H., D. S. Adhuri, L. Adrianto, N. L. Andrew, T. Apriliani, T. Daw, L. Evans, L. Garces, E. Kamanyi, R. Mwaipopo, A. H. Purnomo, R. J. Sulu, and D. J. Beare. 2016. An ecosystem approach to small-scale fisheries through participatory diagnosis in four tropical countries. Global Environmental Change 36:56-66. https://doi.org/10.1016/j.gloenvcha.2015.11.005

Eriksson, H., J. Albert, S. Albert, R. Warren, K. Pakoa, and N. Andrew. 2017. The role of fish and fisheries in recovering from natural hazards: lessons learned from Vanuatu. Environmental Science \& Policy 76:50-58. https://doi.org/10.1016/j.envsci.2017.06.012

Finkbeiner, E. M. 2015. The role of diversification in dynamic small-scale fisheries: lessons from Baja California Sur, Mexico. Global Environmental Change 32:139-152. https://doi.org/10.1016/ j.gloenvcha.2015.03.009

Foale, S. 2001. 'Where's our development?' Landowner aspirations and environmentalist agendas in Western Solomon Islands. Asia Pacific Journal of Anthropology 2(2):44-67. https:// doi.org/10.1080/14442210110001706105

Foale, S., L. Wini, and L. Fernandes. 2017. The Arnavon Community Marine Conservation Area: a review of successes, challenges and lessons learned. Secretariat of the Pacific Regional Environment Programme, Apia, Samoa.

Fuller, R. 2017. Measuring impact: a meta-analysis of Oxfam's livelihood effectiveness reviews. Oxfam Research Report. Oxfam International, Oxford, UK. https://doi.org/10.21201/2017.1091

Garret, J. L., and M. T. Ruel. 1999. Are determinants of rural and urban food security and nutritional status different? Some insights from Mozambique. World Development 27:1955-1975. https://doi.org/10.1016/S0305-750X(99)00091-1

Gautam, Y., and P. Andersen. 2016. Rural livelihood diversification and household well-being: insights from Humla, Nepal. Journal of Rural Studies 44:239-249. https://doi. org/10.1016/j.jrurstud.2016.02.001

Genoni, M. E. 2012. Health shocks and consumption smoothing: evidence from Indonesia. Economic Development and Cultural Change 60(3):475-506. https://doi.org/10.1086/664019

Gillett, R., G. Preston, W. Nash, H. Govan, T. Adams, and M Lam. 2008. Livelihood diversification as a marine resource management tool in the Pacific Islands: lessons learned. SPC Fisheries Newsletter 125:32-39.

Goto, A. 1996. Lagoon life among the Langalanga, Malaita Island, Solomon Islands. Senri Ethnological Studies 42:11-53.

Govan, H. 2011. How can we support communities to build on what they have for a better life? Supplementary livelihoods in the Pacific. Foundation for the Peoples of the South Pacific International (FSPI) Reports, Suva, Fiji.

Govan, H., H. Eriksson, M. Batalofo, A. Duarte, M. Sukulu, S. Lawless, A. Tilley, and J. van der Ploeg. 2019. A new idea for coastal fisheries: asking the right questions to enhance coastal livelihoods. WorldFish, the Pacific Community, the LocallyManaged Marine Area (LMMA) Network and the University of Wollongong, Noumea, New Caledonia. [online] URL: https:// coastfish.spc.int/en/component/content/article/509 
Guo, P. Y. 2006. From currency to agency: shell money in contemporary Langalanga, Solomon Islands. Asia-Pacific Forum 31(3):17-38.

Guo, P. Y. 2011. Torina (canoe making magic) and "copy cat": history and discourses on the boatbuilding industry in Langalanga, Solomon Islands. Pacific Asia Inquiry 2(1):33-52.

Haider, L. J., W. Boonstra, G. D. Peterson, and M. Schlüter. 2018. Traps and sustainable development in rural areas: a review. World Development 101:311-321. https://doi.org/10.1016/j.worlddev.2017.05.038

Hambrey, J., H. Govan, and C. Carleton. 2011. Opportunities for the development of the Pacific islands' mariculture sector: report to the Secretariat of the Pacific Community (SPC). SPC, Noumea, New Caledonia.

Hanh, T. T. H., and W. J. Boonstra. 2018. Can income diversification resolve social-ecological traps in small-scale fisheries and aquaculture in the Global South? A case study of response diversity in the Tam Giang lagoon, central Vietnam. Ecology and Society 23(3):16. https://doi.org/10.5751/ES-10207-230316

IMM Ltd. 2008. Sustainable livelihoods enhancement and diversification (SLED): a manual for practitioners. IUCN, Gland, Switzerland, CORDIO, Kalmar, Sweden, and ICRAN, Cambridge, UK. [online] URL: https://www.iucn.org/sites/dev/ files/import/downloads/sled final 1.pdf

Ivens, W. G. 1930. The island builders of the Pacific: how \& why the people of Mala construct their artificial islands, the antiquity $\&$ doubtful origin of the practice, with a description of the social organization, magic \& religion of their inhabitants. Seeley, Service \& Company limited, London, UK.

Jennings, S., and J. I. Manlutac. 2015. A companion guide to resilience: practical guidance for people designing and implementing programmes that aim to increase the resilience of people living in poverty. Oxfam International, Oxford, UK.

Kotschy, K., R. Biggs, T. Daw, C. Folke, and P. C. West. 2015. Principle 1 - maintain diversity and redundancy. Pages 50-79 in R. Biggs, M. Schlüter, and M. L. Schoon, editors. Principles for building resilience: sustaining ecosystem services in socialecological systems. Cambridge University Press, Cambridge, UK. https://doi.org/10.1017/cbo9781316014240.004

Krantz, L. 2001. The sustainable livelihood approach to poverty reduction: an introduction. Swedish International Development Cooperation Agency (Sida), Division for Policy and SocioEconomic Analysis, Stockholm, Sweden.

Lauer, M. 2014. Calamity, kastom, and modernity: local interpretations of vulnerability in the western Pacific. Environmental Hazards 13(4):281-297. https://doi. org/10.1080/17477891.2014.921594

Logan, M. 2010. Biostatistical design and analysis using $R$ : $a$ practical guide. Wiley-Blackwell, Chichester, UK. https://doi. org/10.1002/9781444319620

Maxwell, S., and M. Smith. 1992. Household food security: a conceptual review. Pages 1-72 in S. Maxwell, and $\mathrm{T}$. Frankenberger, editors. Household food security: concepts, indicators, and measurements: a technical review. United Nations Children's Fund (UNICEF) and International Fund for Agricultural Development (IFAD), New York and Rome.
Mills, D., A. Tilley, M. Pereira, D. Hellebrandt, A. P. Fernandes, and P. J. Cohen. 2017. Livelihood diversity and dynamism in Timor-Leste: insights for coastal resource governance and livelihood development. Marine Policy 82:206-215. https://doi. org/10.1016/j.marpol.2017.04.021

Moore, C. 2017. Making Mala: Malaita in Solomon Islands, 1870s-1930s. ANU Press, Canberra, Australia.

Morse, S., and N. McNamara. 2013. Sustainable livelihood approach: a critique of theory and practice. Springer Science+ Business Media, Dordrecht The Netherlands.

Narsey, W. 2011. The incidence of poverty in Solomon Islands: The importance of methodology. Journal of Pacific Studies 31 (1):31-58

O'Garra, T. 2007. Supplementary livelihood options for Pacific Island communities: a review of experiences. Foundation of the Peoples of the South Pacific International (FSPI), Suva, Fiji.

Oksanen, J., F. G. Blanchet, M. Friendly, R. Kindt, P. Legendre, D. McGlinn, P. R. Minchin, R. B. O'Hara, G. L. Simpson, P. Solymos, et al. 2013. vegan: Community Ecology Package, version 2.5-5. [online] URL: http://cran.r-project.org/web/packages/ vegan/

Olayemi, A. O. 2012. Effects of family size on household food security in Osun State, Nigeria. Asian Journal of Agriculture and Rural Development 2(2):136-141.

Orirana, G., F. Siota, P. Cohen, T. Atitete, A. M. Schwarz, and H. Govan. 2016. Spreading community-based resource management: testing the 'lite-touch' approach in Solomon Islands. SPC Traditional Marine Resource Management and Knowledge Information Bulletin 37:3-12.

Provincial Government Strengthening Program (PGSP). 2016. Ward profile Langalanga (ward 30). Malaita Provincial Government, Auki, Solomon Islands.

Roeger, J., S. Foale, and M. Sheaves. 2016. When 'fishing down the food chain' results in improved food security: evidence from a small pelagic fishery in Solomon Islands. Fisheries Research 174:250-259. https://doi.org/10.1016/j.fishres.2015.10.016

Schwarz, A. M., N. Andrew, H. Govan, D. Harohau, and J. Oeta. 2013. Solomon Islands Malaita Hub scoping report. Project Report: AAS-2013-18. CGIAR Research Program on Aquatic Agricultural Systems, Penang, Malaysia.

Scoones, I. 2009. Livelihoods perspectives and rural development. Journal of Peasant Studies 36:171-196. https://doi. org/10.1080/03066150902820503

Secretariat of the Pacific Community (SPC). 2015. A new song for coastal fisheries - pathways to change: the Noumea strategy. SPC, Noumea, New Caledonia.

Silvestri, S., S. Douxchamps, P. Kristjanson, W. Förch, M. Radeny, I. Mutie, F. C. Quiros, M. Herrero, A. Ndungu, N. Ndiwa, et al. 2015. Households and food security: lessons from food secure households in East Africa. Agriculture and Food Security 4:23. https://doi.org/10.1186/s40066-015-0042-4

Snowdon, W., A. Raj, E. Reeve, R. Guerrero, J. Fesaitu, K. Cateine, and C. Guignet. 2013. Processed foods available in the 
Pacific Islands. Globalization and Health 9:53. https://doi. org/10.1186/1744-8603-9-53

Solomon Islands National Statistics Office(SINSO). 2011. Report on 2009 population \& housing census. Basic tables and census description (Volume 1). SINSO, Honiara, Solomon Islands.

Sukulu, M., G. Orirana, D. Oduagalo, B. Waleilia, R. J. Sulu, A. M. Schwarz, J. van der Ploeg, and H. Eriksson. 2016. 'Management over ownership': towards community-based natural resource management in Langalanga Lagoon, Solomon Islands. SPC Traditional Marine Resource Management and Knowledge Information Bulletin 37:13-21.

Sulu, R. J., H. Eriksson, A.-M. Schwarz, N. L. Andrew, G. Orirana, M. Sukulu, J. Oeta, D. Harohau, S. Sibiti, A. Toritela, and D. Beare. 2015. Livelihoods and fisheries governance in a contemporary Pacific Island setting. PLoS ONE 10(11): e0143516. https://doi.org/10.1371/journal.pone.0143516

Teioli, H. M., J. van der Ploeg, A. M. Schwarz, M. Sukulu, and H. Eriksson. 2018. Conserving womangroves: assessing the impacts of improved cooking stoves on resource management in Langalanga Lagoon, Solomon Islands. SPC Women in Fisheries Information Bulletin 28:8-14.

United Nations Development Programme (UNDP). 2018. Solomon Islands youth status report. UNDP, New York, New York, USA. [online] URL: https://www.undp.org/content/dam/ fiji/docs/UNDP-SOI-Youth-Status-Report-2018.pdf

van der Ploeg, J., J. Albert, M. Apgar, G. Bennett, D. Boso, P. Cohen, C. Daokalia, J. Faiau, D. Harohau, and E. Iramo. 2015. Learning from the lagoon: research in development in Solomon Islands. Program Report: AAS-2016-02. CGIAR Research Program on Aquatic Agricultural Systems, Penang, Malaysia.

Wood, A. L., J. R. Butler, M. Sheaves, and J. Wani. 2013. Sport fisheries: opportunities and challenges for diversifying coastal livelihoods in the Pacific. Marine Policy 42:305-314. https://doi. org/10.1016/j.marpol.2013.03.005

World Bank. 2017. Solomon Islands - systematic country diagnostic: priorities for supporting poverty reduction and promoting shared prosperity. World Bank, Washington, D.C., USA.

World Health Organization (WHO) 2009. Practical guidance for scaling up health service innovations. WHO, Geneva, Switzerland. 
Appendix 1. Survey questionnaire

Please click here to download file 'appendix1.pdf'. 
Ecology and Society 25(4): 18 https://www.ecologyandsociety.org/vol25/iss4/art18/

Appendix 2. Sample sizes

Please click here to download file 'appendix2.pdf'. 